University of Nebraska - Lincoln

DigitalCommons@University of Nebraska - Lincoln

$4-11-2005$

\title{
Lack of Significant Changes in the Herpetofauna of Theodore Roosevelt National Park, North Dakota, Since the 1920s
}

Blake R. Hossack

Aldo Leopold Wilderness Research Institute

Paul Stephen Corn

Aldo Leopold Wilderness Research Institute

David S. Pilliod

Aldo Leopold Wilderness Research Institute, dpilliod@usgs.gov

Follow this and additional works at: https://digitalcommons.unl.edu/usgsstaffpub

Part of the Earth Sciences Commons

Hossack, Blake R.; Corn, Paul Stephen; and Pilliod, David S., "Lack of Significant Changes in the Herpetofauna of Theodore Roosevelt National Park, North Dakota, Since the 1920s" (2005). USGS Staff -Published Research. 92.

https://digitalcommons.unl.edu/usgsstaffpub/92

This Article is brought to you for free and open access by the US Geological Survey at DigitalCommons@University of Nebraska - Lincoln. It has been accepted for inclusion in USGS Staff -- Published Research by an authorized administrator of DigitalCommons@University of Nebraska - Lincoln. 


\title{
Lack of Significant Changes in the Herpetofauna of Theodore Roosevelt National Park, North Dakota, Since the 1920s
}

\author{
BLAKE R. HOSSACK, ${ }^{1}$ PAUL STEPHEN CORN \\ U.S. Geological Survey, Aldo Leopold Wilderness Research Institute, \\ P.O. Box 8089, Missoula, Montana 59807 \\ AND \\ DAVID S. PILLIOD ${ }^{2}$ \\ U.S. Forest Service, Aldo Leopold Wilderness Research Institute, \\ P.O. Box 8089, Missoula, Montana 59807
}

\begin{abstract}
We surveyed 88 upland wetlands and 12 1-km river sections for amphibians in Theodore Roosevelt National Park, North Dakota, during 2001-2002 to gather baseline data for future monitoring efforts and to evaluate changes in the distribution of species. We compared our results to collections of herpetofauna made during 1920-1922, 1954 and 1978-1979. The boreal chorus frog (Pseudacris maculata) was the most common amphibian in upland wetlands, followed by the tiger salamander (Ambystoma tigrinum), Woodhouse's toad (Bufo woodhousii), northern leopard frog (Rana pipiens), plains spadefoot (Spea bombifrons) and the Great Plains toad (B. cognatus). Bufo woodhousii was the only species that bred in the river. Our records for reptiles are less complete than for amphibians but no losses from the community are evident. The herpetofauna in Theodore Roosevelt National Park seems unchanged during at least the last half-century and likely since 1920-1922.
\end{abstract}

\section{INTRODUCTION}

Conversion to agriculture, loss of wetlands and changes in the historic fire and grazing regimes have dramatically altered the Great Plains (Samson and Knopf, 1996). Yet, Corn and Peterson (1996) and Scott (1996) concluded that, with a few exceptions, there was little evidence of significant declines in distribution of amphibians and reptiles inhabiting mid-North American prairies. Recent studies, however, have documented declines of herpetofauna at some locations in prairie regions by comparing historical and modern records of species presence (Lannoo et al., 1994; Busby and Parmalee, 1996; Thurow, 1999; Brodman et al., 2002; McLeod, 2005).

Documenting changes in status of herpetofauna can be difficult because baseline data are rarely available. However, three previous collection efforts in Theodore Roosevelt National Park (THRO), North Dakota, have provided a record of amphibians and reptiles present in the park. The earliest collections were made during 1920-1922 (described by Wheeler and Wheeler, 1966). G. C. Wheeler made numerous collections during the 1950s (Wheeler, 1954; Wheeler and Wheeler, 1966) and Hopkins (1983) studied the distribution of the park's herpetofauna relative to different terrestrial and aquatic habitats.

We surveyed all known upland lentic water bodies and $121-\mathrm{km}$ river sections in THRO during 2001-2002 to provide an inventory of the amphibian community for future

\footnotetext{
${ }^{1}$ Corresponding author

${ }^{2}$ Present address: Department of Biological Sciences, California Polytechnic State University, San Luis Obispo 93407
} 


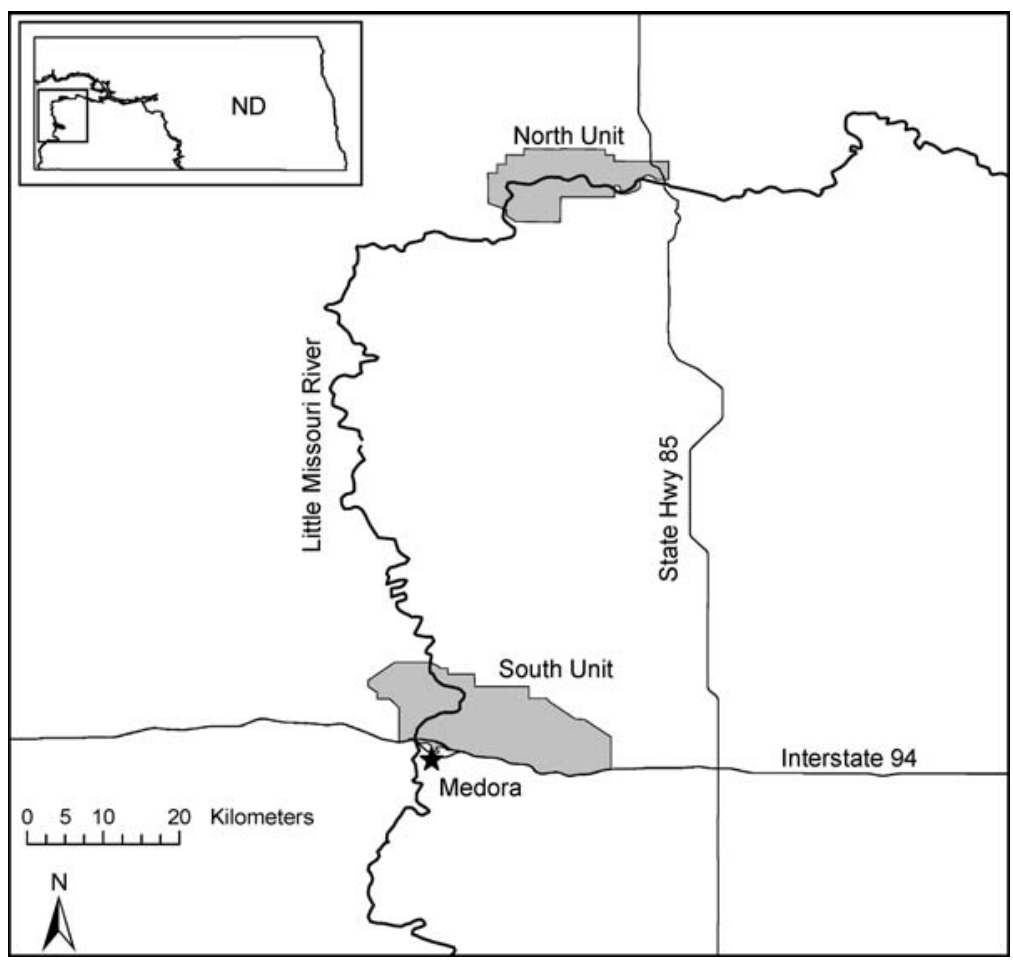

FIG. 1.-Location of the South and North units of Theodore Roosevelt National Park on the Little Missouri River, North Dakota

monitoring efforts. We also conducted calling surveys for amphibians and recorded incidental sightings of reptiles. The well documented record of herpetofauna in THRO allowed us to compare current species richness to that of 1920-1922, 1954 and 1978-1979 to assess potential changes in the park's herpetofauna.

\section{Methods}

STUDY AREA

First established as a National Wildlife Refuge in 1946 and transferred to the National Park Service in 1948, THRO is a 28,509 ha reserve in the ca. 520,000 ha Little Missouri Badlands of southwest North Dakota. The park is divided into two units: the South Unit (18,680 ha) located at Medora in Billings County, and the North Unit (9741 ha) approximately $60 \mathrm{~km}$ north in McKenzie County (Fig. 1). The remaining acreage is at the 88 ha Elkhorn Ranch and an expansion area just east of the Elkhorn Ranch that may be added to the park in the future, both of which are situated between the two units on the Little Missouri River. Topographic relief varies widely within the park, including both relatively flat uplands and deeply-incised canyons and stream courses, but the Little Missouri River drops only $7 \mathrm{~m}$ in elevation on its course from the South Unit through the North Unit (683-676 m). Approximately $23 \%$ of the South Unit (4253 ha) and $81 \%$ of the North Unit (7855 ha) 
are Federally designated wilderness areas. The park is surrounded by the mixed-grass prairie and badlands of the Little Missouri National Grassland.

The Little Missouri Badlands has a semi-arid continental climate, typified by long cold winters and short warm summers. The region averages approximately $38 \mathrm{~cm}$ of precipitation annually, much of it coming in the form of rain from April to July (Jensen, 1972). Other than the Little Missouri River, permanent water bodies are scarce in THRO. The park has increased the amount of permanent water by developing numerous springs and wells to support large mammals.

\section{PRECIPITATION}

Precipitation in the northern Great Plains is highly variable and could affect detection of species. Monthly precipitation records were obtained for weather stations in Medora, adjacent to the South Unit of the park, and Watford City, $24 \mathrm{~km}$ north of the North Unit of the park. Data were available from 1948 to 2002 for the Medora station, and for 1948-1966, 1968-1976 and 1992-2002 for the Watford City station (EarthInfo Inc., Boulder CO, 2004). Use of data from two stations minimized the effect of missing records and should be more representative of precipitation in the area.

\section{HISTORICAL RECORDS}

Wheeler described early collections of amphibians and reptiles throughout North Dakota (Wheeler, 1947; Wheeler and Wheeler, 1966) and in THRO specifically (Wheeler, 1954), providing a record of specimens cataloged in various museums and his personal observations. The first surveys of the area were made near Medora between 1920-1922 through a cooperative arrangement between the University of Michigan Museum of Zoology and the University of North Dakota. Wheeler collected numerous specimens in the South and North units of the park in the 1950s, but collected all amphibian and reptiles species known to THRO at that time during 1954. Hopkins (1983) collected 135 amphibian and reptile specimens while studying the habitat associations of vertebrates in THRO. Location records for numerous other observations in the Hopkins (1983) study were provided by Hansen et al. (1980).

We queried all museums the park or Wheeler $(1947 ; 1954)$ listed as having amphibian or reptile specimens collected in THRO or in Billings or McKenzie counties. Specimens collected by Hopkins (1983) were originally deposited at the University of South Dakota, but were transferred to the University of Nebraska State Museum (UNSM). We located collection records in the US National Museum of Natural History (USNM), University of Michigan Museum of Zoology (UMMZ), University of Nebraska State Museum and the Biology Department of the University of North Dakota (UND). Several specimens collected during 1920-1922 (UMMZ) were labeled as Peaceful Valley Ranch (now inside the South Unit of the park), Medura (presumably Medora) or Medora, the location of park headquarters. We treat records that referenced Medora, but lacked more specific locality information as park records because if a species was found in Medora, it was likely also present in the area that later became THRO. We grouped records from the two park units together because survey efforts have been much greater in the South Unit. The resulting list of collected specimens (Table 1) is not exhaustive, but it allows us to compare faunal records from three previous efforts to document the herpetofauna in THRO.

SURVEYS

All non-flowing water bodies (hereafter, wetlands), including oxbows, were considered potential amphibian breeding habitats and treated as discrete sites. Wetlands were identified using National Wetlands Inventory maps, U. S. Geological Survey 7.5' topographic maps, and 
TABLE 1.-Summary of amphibians and reptiles documented in Theodore Roosevelt National Park during 1920-1922 (University of Michigan Museum of Zoology), 1954 (University of North Dakota Biology Department), 1978-1979 (University of Nebraska State Museum) and 2001-2002

\begin{tabular}{|c|c|c|c|c|}
\hline & \multicolumn{4}{|c|}{ Survey period } \\
\hline & $1920-1922$ & 1954 & $1978-1979$ & 2001-2002 \\
\hline \multicolumn{5}{|l|}{ Amphibians } \\
\hline Ambystoma tigrinum & Present & Present & Present & Present \\
\hline Bufo cognatus & Not Collected & Present & Present & Present \\
\hline Bufo woodhousii & Present & Present & Present & Present \\
\hline Pseudacris maculata & Present & Present & Present & Present \\
\hline Rana pipiens & Not Collected & Present & Present & Present \\
\hline Spea bombifrons & Present & Present & Present & Present \\
\hline \multicolumn{5}{|l|}{ Reptiles } \\
\hline Chrysemys picta & Not Collected & Not Collected & Not Collected & Present \\
\hline Coluber constrictor & Present & Present & Present & Present \\
\hline Critalus viridus & Present & Present & Present & Present \\
\hline Heterodon nasicus & Present & Present & Present & Present \\
\hline Phyrnosoma hernandesi & Present & Present & Present & Not Found ${ }^{\mathrm{a}}$ \\
\hline Pituophis catenifer & Present & Present & Present & Present \\
\hline Scleroporus graciosus & Present & Present & Present & Not Found ${ }^{b}$ \\
\hline Thamnophis radix & Present & Present & Present & Present \\
\hline
\end{tabular}

${ }^{a}$ Seen by M. Oehler (Theodore Roosevelt National Park) in 2004

${ }^{\text {b }}$ Seen by C. Beachy (Minot State University) in 1998

National Park Service maps of developed springs and wells. We also found many unmapped wetlands. Wetlands on private in-holdings in the North Unit and a few developed wells that lacked surface water were not surveyed. Surveyed wetlands included developed stock ponds, natural ponds, developed springs that overflowed from cattle tanks, undeveloped springs, roadside pools and bison wallows. We estimated the hydroperiod of wetlands during each survey as temporary, semi-permanent or permanent based on the depth of each wetland.

Surveys were conducted between 01 May-29 June 2001 and 16 May-22 July 2002 by slowly walking the perimeter or near-shore area of wetlands while searching for amphibians. Dip nets were used in areas with vegetation or where water clarity was poor. We recorded all life history stages (embryo, larva, juvenile or adult) of species found but detection of embryos or larvae was emphasized because we did not search under objects such as rocks or logs for adults. Many wetlands were surveyed more than once each year to increase the chances of detecting species.

We surveyed potential amphibian breeding sites in the floodplain of the Little Missouri River in 2001 by dividing the river into $1-\mathrm{km}$ reaches (16 in the South Unit and 17 in the North Unit). We randomly selected eight reaches from each unit. Wetlands within the river floodplain were formed by receding waters after rainstorms and were surveyed using the same methods as for upland sites.

We also conducted road-based nighttime surveys for calling amphibians after a rainstorm in 2001. Observers listened for $5 \mathrm{~min}$ at 21 calling stations in the South Unit on 13 June and 14 stations in the North Unit on 14 June. Calling stations were located at road pullouts, bridges and mile-markers. We supplemented data from amphibian surveys with incidental sightings of reptiles made during surveys and while traveling between sites. Voucher specimens (mainly embryos and larvae of amphibians) were submitted to the THRO museum. 


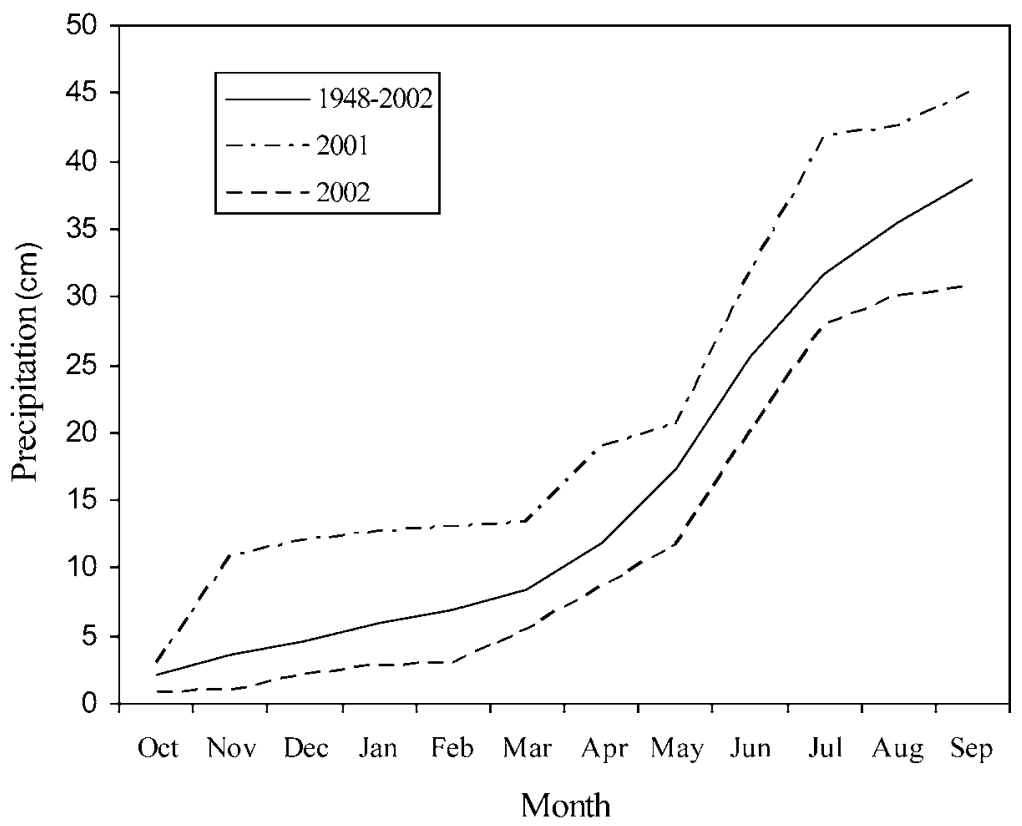

Fig. 2.-Average cumulative annual precipitation $(\mathrm{cm})$ for the Medora and Watford City, North Dakota, weather stations in 2001, 2002 and the mean for 1948-2002

\section{RESULTS}

\section{PRECIPITATION}

The Medora and Watford City weather stations averaged $37.80 \mathrm{~cm}(\mathrm{SD}=8.76)$ and 40.31 $\mathrm{cm}(\mathrm{SD}=7.85)$ cumulative precipitation since 1948 , respectively, coming mostly as rain during the spring and summer months (Fig. 2). Surveys in May-June 2001 were conducted during wetter than normal conditions (Fig. 2). Precipitation during November 2000 greatly exceeded the average for that month, which likely provided more water to fill temporary wetlands the following spring. Surveys in May-July 2002 were conducted during drier than normal conditions. Surveys by Wheeler during 1954 (mean of Medora and Watford City weather stations: $46.31 \mathrm{~cm}$ ) and Hopkins (1983; Medora weather station: $44.75 \mathrm{~cm}$ in 1977 , $49.05 \mathrm{~cm}$ in 1978) were conducted during years with above-average precipitation.

\section{SPECIES OCCURRENCES}

We surveyed 88 upland wetlands in 2001-2002: 57 in the South Unit and 31 wetlands in the North Unit. Fifty-seven wetlands were surveyed an average of 1.46 times each in 2001. Sixty-nine wetlands were surveyed an average of 1.87 times each in 2002. In 2002, 19 wetlands that were surveyed in 2001 never filled with water but an additional 31 wetlands were found. Our estimates of hydroperiod for the same wetlands were sometimes variable within and between years, but most wetlands were temporary. In 2001, we conducted single surveys of 32 wetlands in twelve 1-km river reaches ( 4 of 8 selected reaches in the North Unit were not surveyed due to flooding).

Six species of amphibians were found during 2001-2002 (Table 2). The boreal chorus frog (Pseudacris maculata) was the most common amphibian in upland wetlands, followed by 
TABLE 2.-Number of amphibian breeding sites detected in upland wetlands in Theodore Roosevelt National Park in 2001, 2002, wetlands used for breeding in both years, and the total of breeding sites for each species. Numbers in parentheses below column headings are the number of wetlands surveyed

\begin{tabular}{lcccc}
\hline \hline \multicolumn{1}{c}{ Species } & $\begin{array}{c}2001 \\
(\mathrm{n}=57)\end{array}$ & $\begin{array}{c}2002 \\
(\mathrm{n}=69)\end{array}$ & $\begin{array}{c}2001 \text { and } 2002 \\
(\mathrm{n}=38)\end{array}$ & $\begin{array}{c}\text { Total breeding sites } \\
(\mathrm{n}=88)\end{array}$ \\
\hline Ambystoma tigrinum & 11 & 13 & 6 & 18 \\
Bufo cognatus & 0 & 0 & 0 & 0 \\
Bufo woodhousii & 12 & 11 & 6 & 17 \\
Pseudacris maculata & 27 & 18 & 8 & 37 \\
Rana pipiens & 5 & 10 & 3 & 12 \\
Spea bombifrons & 3 & 4 & 1 & 6 \\
\hline
\end{tabular}

the tiger salamander (Ambystoma tigrinum), Woodhouse's toad (Bufo woodhousii), northern leopard frog (Rana pipiens), plains spadefoot (Spea bombifrons) and the Great Plains toad (Bufo cognatus). Four species (A. tigrinum, B. woodhousii, P. maculata and R. pipiens) were found breeding in both units of the park. Our only detection of $B$. cognatus was an incidental sighting of an adult female near the mouth of Knutson Creek in June 2001. Ambystoma tigrinum and $R$. pipiens were most commonly found in wetlands estimated to be either semipermanent or permanent.

Surveys of the river floodplain resulted in detection of Bufo woodhousii tadpoles at nine sites. Calling surveys detected B. woodhousii, Pseudacris maculata, Rana pipiens and Spea bombifrons. Calling surveys were more effective than wetland surveys for detecting $S$. bombifrons. We documented calling by $S$. bombifrons at 11 of 21 stops in the South Unit and 11 of 14 stops in the North Unit, compared to 6 breeding sites detected by wetland surveys.

We found six species of reptiles during searches for amphibians and while traveling between wetlands: western painted turtle (Chrysemys picta), racer (Coluber constrictor), prairie rattlesnake (Crotalus viridus), western hognose snake (Heterodon nasicus), bullsnake (Pituophis catenifer) and plains garter snake (Thamnophis radix; Table 1).

\section{Discussion}

We found the same six amphibian species during 2001-2002 that were documented in 1954 (UND) and during 1978-1979 (Hopkins, 1983; Table 1). Four of these species (Ambystoma tigrinum, Bufo woodhousii, Pseudacris maculata and Spea bombifrons) were first documented in or next to the South Unit in 1920-1922 (UMMZ) and have been found during every survey since then. Surprisingly, we were unable to find documentation of Rana pipiens in THRO until 1953 (UND), although its presence had been documented elsewhere in the Little Missouri Badlands by 1926 (UMMZ). We consider it likely that it was in the park during the 1920-1922 survey, but it was not collected. Bufo cognatus, first collected in 1953 (UND), is the most recent addition to the list of amphibian species in THRO.

Of the amphibian species in THRO, widespread declines have been reported only for Rana pipiens. Populations have declined throughout much of central and western North America (Roberts, 1987; Lannoo et al., 1994; Corn, 2000). We encountered $R$. pipiens more frequently than previous surveys in THRO, but comparisons of relative abundance are not possible because the four surveys of the park have used different techniques. All 12 documented $R$. pipiens breeding sites were in deeper wetlands estimated to be semipermanent or permanent.

Ambystoma tigrinum was common in both units of the park. As with Rana pipiens, however, we suspect the distribution of A. tigrinum in THRO may be limited by the short hydroperiod 
of most wetlands in the park because 14 of 18 breeding sites were estimated to be semipermanent or permanent.

Bufo woodhousii was abundant in both units of the park. Adults were commonly seen during the day from May through July and bred in all types of wetlands. It was also the only species we found breeding in the river. Considering incidental sightings of adults along with wetland surveys, $B$. woodhousii was the most commonly seen species. Hansen et al. (1980) also described B. woodhousii as common during 1978-1979.

Pseudacris maculata was the most common amphibian at upland wetlands in both units of THRO and it is common across most of North Dakota (Bowers et al., 1998; Johnson and Batie, 2001). Museum collections and sighting accounts in the Badlands do not seem to reflect its abundance, however. We are not sure why previous surveys rarely encountered this species, but suggest the different results may be due to timing and methodology of surveys. Seabloom et al. (1978) and Hopkins (1983) focused on multiple vertebrate species and did not emphasize detection of amphibian larvae. We suspect Wheeler made most of his collections during nighttime road surveys because most specimens he collected were near roads (UND), and $P$. maculata is probably less likely than larger anurans to be included in road collections because its small size $(2-4 \mathrm{~cm})$ makes it more difficult to detect. We located many unmapped wetlands by following the sound of daytime P. maculata breeding choruses and heard it throughout both units of the park during calling surveys.

Wetland surveys are not ideal for detection of Spea bombifrons because it has a limited activity period and short larval period (Klassen, 1998). Based on the distribution of breeding sites and calling heard during June 2001, it seems widespread in both units of THRO. All breeding sites were temporary wetlands that filled after rainstorms. We heard breeding choruses in the North Unit but did not find larvae during either year of surveys. Bufo cognatus has a similar activity pattern as $S$. bombifrons and has never been reported as common in the park. It was not documented in the western one-third of North Dakota until after 1947 (Wheeler, 1947), but it is common outside of the southwestern portion of the state (Johnson and Batie, 2001). The female we found in the South Unit confirms $B$. cognatus is still present but no breeding sites or choruses have been reported in THRO.

Our greater focus on upland wetlands likely influenced the perceived abundance of some amphibians. Many amphibians in the Great Plains breed in ephemeral pools, which are less reliably mapped and are therefore less likely to be surveyed. We suspect a greater emphasis on locating and surveying ephemeral pools would increase detections of Spea bombifrons and Bufo cognatus. Similarly, we did not attempt to inventory the numerous intermittent streams. We occasionally heard amphibians calling from streams or saw larvae in them, but with the unpredictable water flows we are unsure whether these habitats represent viable breeding habitats or whether larvae are routinely flushed downstream with each rainstorm. After heavy summer rains in 2001, we revisited several locations where B. woodhousii larvae were seen in isolated pools in drying streams or within the river floodplain and all of the larvae had been washed away. It is possible that during summers without large rain events or if there is sufficient time between rain events, many breeding sites in streams and along the Little Missouri River may result in successful recruitment.

All of our records for reptiles are incidental observations while searching for amphibians or traveling between wetlands. However, we found all reptiles previously documented in THRO except for the greater short-horned lizard (Phrynosoma hernandesi) and sagebrush lizard (Sceloporus graciosus). The Badlands is the eastern limit of the range in North Dakota for $P$. hernandesi and $S$. graciosus and both are distributed patchily in the area (Wheeler and Wheeler, 1966). Phrynosoma hernandesi (M. Oehler, THRO, pers. comm.) and S. graciosus (C. Beachy, Minot State University, pers. comm.) were seen in THRO in 2004 and 1998, 
respectively. The five snake species in THRO were first documented in 1920-1922 and have been recorded during every survey of the park since then (Table 1). We found Chrysemys picta in both units of the park. Chrysemys picta was not reported in previous surveys of THRO, but Hopkins (1983) reported seeing it in ponds just outside of the park. Four additional reptile species have been reported in the surrounding area (Hoberg and Gaus, 1992), but remain undocumented in THRO: spiny softshell (Apalone spinifera), snapping turtle (Chelydra serpentina), smooth greensnake (Opheodrys vernalis) and common garter snake (Thamnophis sirtalis), although C. serpentina (M. Oehler in 2003, pers. comm.) and T. sirtalis (C. Beachy in 1998, pers. comm.) have both been seen in the South Unit of the park.

Comparisons of current and historical records of species presence have been used to document many local extirpations or reductions in abundance, as well as possible range expansions and introductions (Lannoo et al., 1994; Busby and Parmelee, 1996; Fisher and Shaffer, 1996; Brodman et al., 2002). Conclusions about changes in species distributions can be affected by the spatial and temporal context of the study, however (Shaffer et al., 1998; Skelly et al., 2003). Pooling records for the entire park and both years made our results more robust to failing to detect species that were present. Reporting records by park unit would have provided more detailed information for some species, but we did not think it was justified because survey efforts have been unequal in the South and North units. Likewise, short-term surveys increase the chances of missing species (Skelly et al., 2003). If we had surveyed during only 2001 or 2002 we may have missed Bufo cognatus or H. nasicus because each was found only once and in different years.

Recent studies of herpetofauna in the northern Great Plains do not suggest previously common and widespread species have been extirpated. Bowers (1998) incorporated data from Johnson and Batie (2001) in a survey of the Prairie Potholes region of North Dakota and found all nine anurans expected. Corn et al. (1995) found 21 of 25 species of herpetofauna previously documented from Cherry County, Nebraska. In a survey of Wind Cave National Park and adjacent areas in South Dakota, Smith (1996) found 17 of 18 amphibian and reptile species known to occur in the area, and Smith et al. (1997) found 15 of 19 species in surveys of Buffalo Gap National Grasslands and 14 of 18 species in Badlands National Park, South Dakota. A common element to these surveys and our survey of THRO is that species that were not detected were distributed patchily, were secretive and difficult to detect, or were known to be present at locations just outside of the study areas. None of the undetected species were considered absent from the areas in appropriate habitat.

Even though widespread declines in distribution have not been reported for most amphibians and reptiles in North American prairies (Corn and Peterson, 1996; Scott, 1996), it is likely many species are less abundant than they were in the past. Rana pipiens was the most common amphibian in Dickinson County, Iowa, during surveys in 1991-1992 despite an estimated decline in numbers of 2 or 3 orders of magnitude during the $20^{\text {th }}$ Century (Lannoo et al., 1994). McLeod (2005) repeated a state-wide survey of ponds in Nebraska that were first sampled in the $1970 \mathrm{~s}$ and found a $59 \%$ reduction in the number of ponds occupied by amphibian larvae, and reported 7 of 11 species showed some evidence of decline. Lannoo et al. (1994) reported a similar reduction in pond occupancy for $A$. tigrinum. The status and abundance of most reptiles in prairie ecosystems is even less certain than for amphibians.

Three of the aforementioned studies that reported the assemblage of herpetofauna remained intact (Corn et al., 1995; Smith, 1996; Smith et al., 1997) occurred in Federallyprotected areas. Similarly, Busby and Parmelee (1996) concluded there was little change in the species of herpetofauna present in the northern Flint Hills of Kansas during the $20^{\text {th }}$ Century due to the maintenance of native prairie. Many other studies that have compared 
current distributions to historical records have linked declines to habitat loss or introduced species (Lannoo et al., 1994; Thurow, 1999; Brodman et al., 2002; McLeod, 2005), although the widespread decline of Blanchard's cricket frog (Acris crepitans blanchardi) remains largely unexplained (Lannoo, 1998). Given the extensive loss or modification of prairie and wetlands throughout much of the northern Great Plains (Samson and Knopf, 1996), it is possible the herpetofauna of THRO and other Federal lands in the region have been buffered from the effects of habitat loss and that declines have occurred in more disturbed areas. Continued presence of a species does not mean declines in abundance have not occurred, but with the possible exception of C. picta becoming established in the park, the herpetofauna present in THRO seems unchanged since the 1920s.

Acknowledgments. - We thank the staff of Theodore Roosevelt National Park for their cooperation and assistance. We also thank the University of Michigan Museum of Zoology, US National Museum, University of Nebraska State Museum and University of North Dakota Biology Department for museum records. M. Oehler helped decipher locality information of some museum records. Comments by B. Smith, C. Beachy, M. Oehler, W. Sadinski and two anonymous reviewers improved the manuscript. Research was conducted under permits THRO-2001-SCI-0005 and THRO-2002-SCI-0005 and was funded by the U. S. Department of Interior Amphibian Research and Monitoring Initiative.

\section{Literature Cited}

Bowers, D. G. 1998. Anuran survey methods, distribution, and landscape-pattern relationships in the North Dakota Prairie Pothole region. M.S. Thesis, University of Minnesota, St. Paul. 152 p.

, D. E. ANDERSEn ANd N. H. Euliss, Jr. 1998. Anurans as indicators of wetland condition in the Prairie Pothole region of North Dakota: an environmental monitoring and assessment program pilot project, p. 369-378. In: M. J. Lannoo (ed.). Status and conservation of Midwestern amphibians. University of Iowa Press, Iowa City.

Brodman, R., S. Cortwright and A. Resetar. 2002. Historical changes of reptiles and amphibians of northwest Indiana Fish and Wildlife properties. Am. Midl. Nat., 147:135-144.

Busby, W. H. ANd J. R. PARMeleE. 1996. Historical changes in a herpetofaunal assemblage in the Flint Hills of Kansas. Am. Midl. Nat., 135:81-91.

Corn, P. S., M. L. Jennings And R. B. Bury. 1995. Amphibians and reptiles, p. 32-59. In: M. A. Bogan (ed.). A biological survey of Fort Niobrara and Valentine National Wildlife Refuges. National Biological Service, Fort Collins, Colorado.

— and C. R. Peterson. 1996. Prairie legacies - amphibians and reptiles, p. 125-134. In: F. B. Samson, and F. L. Knopf (eds.). Prairie conservation: preserving North America's most endangered ecosystem. Island Press, Covelo, California.

2000. Amphibian declines: review of some current hypotheses, p. 663-696. In: D. W., Sparling G. Linder and C. A. Bishop (eds.). Ecotoxicology of amphibians and reptiles. Society of Environmental Toxicology and Chemistry Press, Pensacola, Florida.

Fisher, R. N. ANd H. B. Shaffer. 1996. The decline of amphibians in California's great Central Valley. Conserv. Biol., 10:387-1397.

Hansen, P. L., R. B. Hopkins and G. R. Hoffman. 1980. An ecological study of the habitat types and their animal components at Theodore Roosevelt National Park, North Dakota. Department of Biology, University of South Dakota, Vermillion. $182 \mathrm{p}$.

Hoberg, T. and C. Gause. 1992. Reptiles and amphibians of North Dakota. N. D. Outdoors, 55:7-19.

Hopkins, R. 1983. Habitat affinities of the herpetofauna of Theodore Roosevelt National Park, North Dakota. Prairie Nat., 15:86-92.

Jensen, R. E. 1972. Climate of North Dakota. North Dakota State Water Commission, Bismarck. 48p.

Johnson, D. H. and R. D. Batie. 2001. Surveys of calling amphibians in North Dakota. Prairie Nat., 33:227-247.

KLASSEN, M. A. 1998. Observations on the breeding and development of the plains spadefoot, Spea bombifrons, in southern Alberta. Can. Field-Nat., 112:387-392. 
LANNOO, M. J. 1998. Amphibian conservation and wetland management in the upper Midwest: a catch22 for the cricket frog? p. 330-339. In: M. J. Lannoo (ed.). Status and conservation of Midwestern amphibians. University of Iowa Press, Iowa City.

— K. Lang, T. WaltZ and G. S. Phillips. 1994. An altered amphibian assemblage: Dickinson County, Iowa, 70 years after Frank Blanchard's Survey. Am. Midl. Nat., 131:311-319.

MCLeOD, D. S. 2005. Nebraska's declining amphibians, p. 292-294. In: M. J. Lannoo (ed.). Amphibian declines: the conservation status of United States species. University of California Press, Berkeley.

Roberts, W. 1987. The northern leopard frog - endangered in Alberta, p. 137-138. In: G. L. Holroyd, P. H. R. Stepney, G. C. Trottier, W. B. McGillivray, D. M. Ealey and K. E. Eberhart (eds.). Endangered species in the prairie provinces. Natural History Occasional Paper No. 9, Provincial Museum of Alberta, Edmonton.

SAmson, F. B. AND F. L. KNopf (eds.). 1996. Prairie conservation: preserving North America's most endangered ecosystem. Island Press, Covelo, California. 339 p.

ScotT, N. J., JR. 1996. Evolution and management of the North American grasslands herpetofauna, p. 40-53. In: D. M. Finch (ed.). Ecosystem disturbance and wildlife conservation in western grasslands. U.S.D.A. Forest Service General Technical Report RM-GTR-285.

Seabloom, R. W., R. D. Crawford and M. G. McKenna. 1978. Vertebrates of southwestern North Dakota: amphibians, reptiles, birds, mammals. Research Report No. 24, University of North Dakota, Grand Forks. 549 p.

Shaffer, H. B., R. N. Fisher and C. Davidson. 1998. The role of natural history collections in documenting species declines. Trends Ecol. Evol., 13:27-30.

Skelly, D. K., K. L. Yurewicz, E. E. Werner and R. A. Relyea. 2003. Estimating decline and distributional change in amphibians. Conserv. Biol., 17:744-751.

Sмiтh, B. E. 1996. A herpetological survey of Wind Cave National Park, South Dakota. U. S. Geological Survey, Northern Prairie Wildlife Research Center, Jamestown, North Dakota. 63 p.

D. M. Browning, E. Taylor, R. S. Ferguson and K. Yturralde. 1997. Herpetofaunal surveys of the Fall River Ranger District, U. S. Forest Service, southwestern South Dakota and Badlands National Park. U. S. Geological Survey, Northern Prairie Wildlife Research Center, Jamestown, North Dakota. $44 \mathrm{p}$.

Thurow, G. R. 1999. Herpetofaunal changes in McDonough County, Illinois. Trans. Ill. Acad. Sci., 92:147-161.

Wheeler, G. C. 1947. The amphibians and reptiles of North Dakota. Am. Midl. Nat., 38:162-190.

1954. The amphibians and reptiles of the North Dakota badlands. Theodore Roosevelt Nature and History Association. Medora, North Dakota. 56 p.

AND J. WheELER. 1966. The amphibians and reptiles of North Dakota. University of North Dakota Press, Grand Forks. 104 p. 